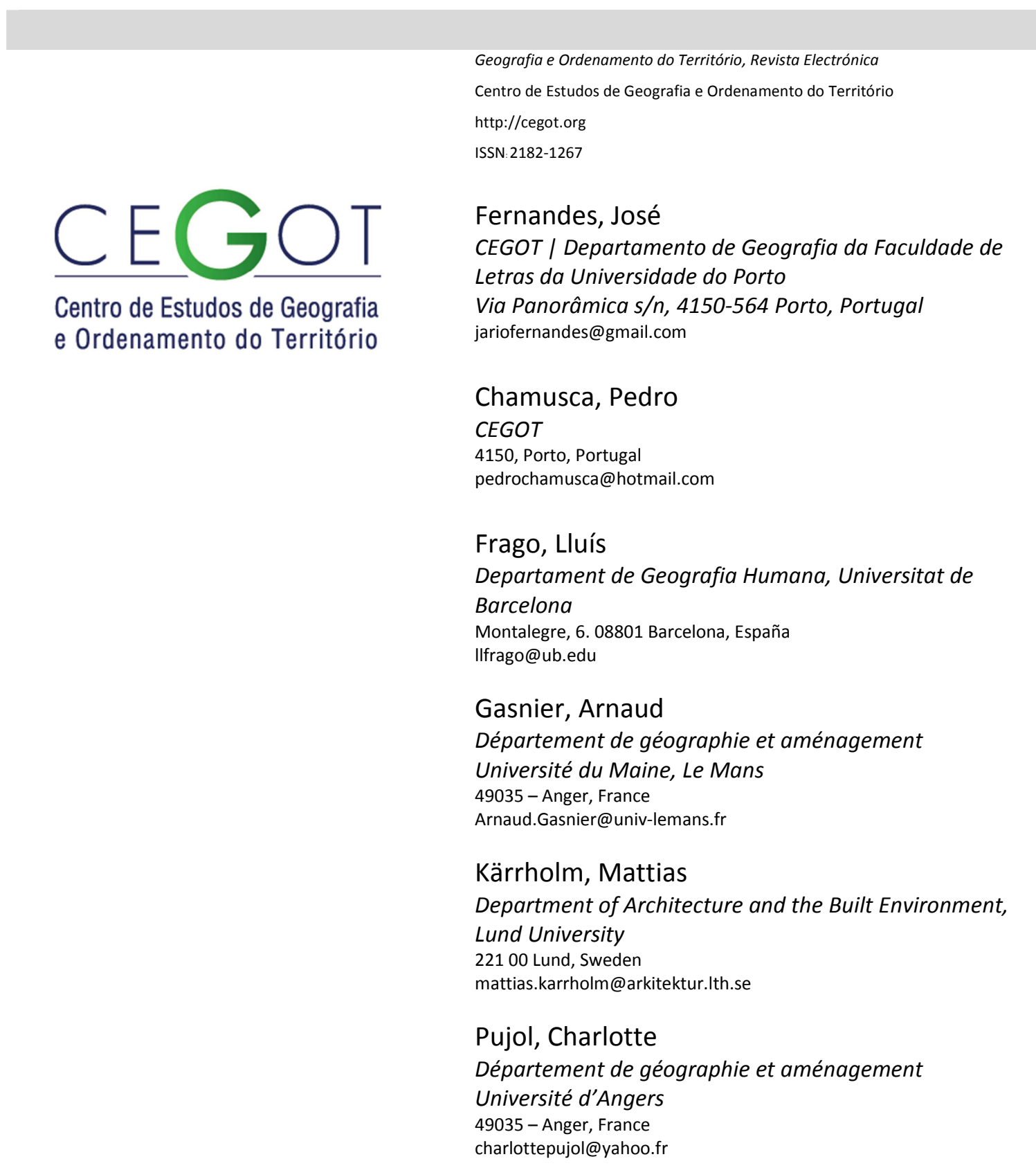

\title{
Time policies, urban policies and planning ${ }^{1}$
}

Referência: Fernandes, José et al. (2015). Time policies, urban policies and planning. (GOT), n.o 7 (junho). Centro de Estudos de Geografia e Ordenamento do Território, p. 129-157, dx.doi.org/10.17127/got/2015.7.006

${ }^{1}$ This work is financed by National funding, by FCT - Fundação para a Ciência e a Tecnologia, within the project «PEst-OE/SADG/UI4084/2014» (Este trabalho é financiado por Fundos Nacionais através da FCT Fundação para a Ciência e a Tecnologia no âmbito do projeto «PEst-OE/SADG/UI4084/2014») 


\title{
Resumo
}

Ao longo das últimas décadas, transformações sociais e económicas muito intensas, conheceram uma tradução em processos de complexificação territorial, fragmentação urbana e crescimento da injustiça de base espacial. A literatura e a investigação desenvolvida sustentam a ideia de que estes processos apresentam uma dimensão temporal não menos importante, associada à transição de um padrão industrial de ritmos sincronizados para uma sociedade heterogénea, na qual as experiências quotidianas são cada vez mais individualizadas e onde um crescente número de pessoas tem agendas e horários de trabalho atípicos. A esse propósito, este artigo, cuja investigação de base está associada ao projeto da Urban-Net Chronotope e aproveita as suas discussões e resultados, centra-se na importância da relação entre políticas do tempo, políticas urbanas e planeamento, dando conta da diferença existente entre países e cidades, a partir da consideração de Porto/Portugal, Barcelona/Espanha, Malmo/Suécia e Toulouse/França.

Palavras-Chave: políticas do tempo; políticas urbanas; planeamento; urbanismo; Europa

\begin{abstract}
Over the past few decades, significant social and economic transformations had a relevant correspondence in processes of territorial complexification, urban fragmentation and spatial injustice. Literature and research shows that these processes have also a very important temporal dimension, associated to a transition from an industrial society of synchronized rhythms to more heterogeneous everyday experiences where more individualized timespace associations of a growing number of people are based on atypical agendas and working hours. This article, that is associated with the Urban-Net project Chronotope, profiting from its discussions and results, takes as central the relation between time policies, urban policies and planning, analyzing differences between Oporto/Portugal, Barcelona/Spain, Malmoe/Sweden and Toulouse/France.
\end{abstract}

Keywords: time policies; urban policies; planning; urbanism; Europe

\section{Introduction}

Velocity and its relation with accessibility are essential to understand recent changes on the process of urbanization; particularly on its physical dimension and on the way it has transformed urban spaces in most of the European countries. Several authors identify the creation of city-regions (Dieleman\&Faludi, 1998; Hall\&Pain, 2006; Neuman\&Hull, 2011; Hall, 2014) as one of the most relevant features of this transformation. But is seems to be no less important to understand recent changes on the way urban spaces are used (and created) in the historical and compact city, as a consequence of the relevance of increased "free time" (holidays, evenings and weekends especially), as well as working time deregulation, and 
time superposition (work+leisure, study+work, ...) to what we have to add the communication revolution and superimpositions of physical and digital network use.

Labor flexibility created a desynchronization of individual and collective rhythms, breaking somehow with the synchronization of European societies that was promoted by the standardization of working hours in the industry that had been expanding since the $19^{\text {th }}$ century. That same flexibility and desynchronization which seems to give more freedom on the use of time specially if associated with velocity, allowing an increased spatial choice, also makes more difficult a good work-life balance, for individuals who do not necessarily have the same rhythms (Boulin \& Mückenberger, 2002) signaling the emergence of a new social and spatial divide.

High velocity in the connection between cities (by air, rail and road) and inside urban regions seem to be more and more complemented by slow movement in central areas, where a certain "back to the city" process is in motion, with tourism, gentrification and cultural consumption all playing important roles. As air and rail travel is increasingly democratized, walking becomes no less important for a great number of people, as mobility becomes more and more relevant in our much-urbanized societies and complex structure of urban spaces.

As a consequence, there has been an increased consideration of time in urban spaces although a not so easy and fast answer to the change from a one objective movement and residence-work commuting domination to a more spatial complex, multipurpose and "afterhours" type of movements, where in some cases times and objectives are superimposed and work is not always easy to separate from "free time". Also, daily movements are more random as occasional journeys are increasing and work-related flows are decreasing. Also decreasing are the shopping-related trips, especially for everyday purchases, while those related to leisure increase, although the bigger increase seem to be related to complex sequences between various motives (work, leisure, education, shopping, etc.) and different situations according to the country and city you live and your economic status.

The increased relevance of mobility has seen the emergence or reinforcement of time-space policies, in different scales and multiple forms. Generally, it is possible to consider the erosion of an association between time, function and space, as our lives become less and less dependent of regulations that determine our times to work, to shop or to relax. It is also crucial to understand that mobility has increased our capacity to choose where and when we do it. As a consequence public policies and planning have a new consideration for time 
and its relation with space, with associations between both the dimensions getting more relevant on plans and urban management regulations, especially in the central city, in face of the diversity of city-users interests.

Taking the relevance of time in the use of space as a central idea, we explore and discuss some of the policies and initiatives that are coming along in Europe, particularly in some countries, with a reference to physical planning, projects and initiatives related with velocity, mobility, and other time-space relations, and a special focus on mid and big size "second cities": Barcelona, Porto, Malmoe and Toulouse. This article is associated with the Urban-Net project Chronotope and profits from its discussions and results. It also considers the relevance of the political action of Italian minister Livia Turco that created legislation in 2000 (Law 53 also known as "Turco Law") enforcing all cities with more than 30.000 inhabitants to have time plans, paving the way for different actions of that type all over Europe.

The main concepts are those that have to do with the movement. Velocity, accessibility and mobility are seen as central, as they deal with an essential condition of citizenship and a relevant asymmetry of our times that separates hypermobile from hipomobile (Ascher, 2002). Even if that is not universal, and there's much "in-between" in this dualism, we believe that spatial injustice is gaining relevance and that is also related with a general increase in mobility that explains the fact that proximity became different from contiguity only for some, meaning that a $5 \mathrm{~m}$ trip by car or a $10 \mathrm{~m}$ trip by urban rail is rather different of the time and effort that someone that has no car and no public transport near its residence has to spent to buy something at a hypermarket that may be located just the other side of the motorway.

The article is organized in six sections (including an introduction) and intends to promote joint reflection and discussion on issues related to time policies, urban policies and planning. On a comparative approach main differences between urban planning and urbanism are analyzed, with an important focus on the consequences of the growth of public-private partnerships and the entrepreneurial city models in the way space is planned and timespace considered. On the third point we discuss recent urban changes, specially those related to "strong words" of the last quarter of the 20th century (as touristification, gentrification and urban sprawl) giving special attention to its relation with planning and the use of time. The fourth section is dedicated to time policies, discussing its emergence, some milestones and evidences of its implementation (or not) in the four cities that had been 
considered. On the fifth part of this text we reflect on some of the major challenges that societies and territories have to face, in relation with time-space diversity, and in final section we present some conclusions and proposals for a more active consideration of time in urban planning and policies.

\section{Time, urban planning and urbanism}

Over the last decades urban planning has had to deal with intense transformations, also noted in the relations of people and space with time. On this aspect and despite some important particularities and the way rhythms and patterns of movement can acquire diverse combinations in different contexts; it is possible to identify some major trends in urban planning and urbanism, with direct or indirect effects on time planning:

- Consolidation of David Harvey's entrepreneurial city principles, deeply associated to the international and regional accessibility in the "competitive and attractive (world) city" (Hall, 1996);

- Growing relevance of private capital interests, with multiplication and diversification of public-private partnerships schemes;

- Expansion of "laissez-faire" and neoliberal approaches to urban management, with entrepreneurial strategies seeking the profitability and optimization of time, sometimes coexisting or with lapses of less liberal and more progressive or conservative visions;

- Increased number and relevance of area-based initiatives of urban planning and intervention (with renovation, beautification, regeneration and touristification), with an emphasis on the most attractive and competitive parts of the cities, especially city center and waterfront areas;

- Less stability on cities governance and planning, with strategic visions more vulnerable than before to institutional and government changes, short-term actions and opportunities that could not be predicted;

- Increased importance of multilevel planning - nor always formally recognized - as a result of metropolization and more intense and complex suburbanization processes, with a explicit or implicit objective of reducing distances, flows and travel times. 
The transformations of the second half of the $20^{\text {th }}$ century had strong consequences on the way mobility of people changed while alterations on mobility contributes a great deal to explain some of the changes of the geography of places in today extended urban spaces. Many times, urban planning (or the lack of it) was responsible for morphological, social and economic fragmentation, amongst other processes and related problems. For instance, in Spain had a massive suburbanization on the transition from the $19 \mathrm{ht}$ to the $20^{\text {th }}$ century, especially around some of the major cities as Barcelona (Carreras, 1993). In Sweden, as well, the concentration of people on a few although extended spaces has been very relevant during the last decades, especially in Stockholm, Gothenburg and Malmö. For that process there's a contribute from an increasing number of immigrants and also more and more visitors, commuters and second residents between Copenhagen and Malmö since the opening of the Oresund bridge in 2001, connecting Sweden and Denmark, as well as planning for densification and branding, with some new built areas projected to attract the middle class back to the city.

In other cities, as Toulouse, in the South of France, there was a combination of urban sprawl and densification process as recent studies of the Toulouse Planning Agency highlight and that have justified the development of multilevel planning. Here, multilevel planning is based on three pillars, aimed at controlling increased urbanization by urban densification; the polarization of development by adopting the principles of functional diversity (to reduce travel distances and travel times) and urban renewal; and a reinforced effort in connecting urban to suburban territories.

In Portugal - taking Oporto as reference - suburbanization was very important, but the diversification of times, spaces and people's interests and "territories" was also crucial to understand the growing relevance of multilevel planning and area-base approaches, much in line with EU urban regeneration funding instruments, with spatial and temporal dimensions helping to promote a mixture of functions and activities, also trying to conciliate history with modernity in the context of sectorial and institutional integrated interventions.

Generally speaking, spatial and temporal compression (Harvey, 1990) - that is related with globalization, especially of capital - and the increasing relevance of private investment in economic development have been forcing nations, regions and cities to compete more and more fiercely. If nations and regions try to lure investment with low taxes and cheap, docile and/or well-trained work force, in the case of cities, much of the attractiveness seems to be 
much related in a quite a lot of cases with the idea that a nice city to the tourists is a nice city to investors and should be nice for residents too.

Apart the much-debated TTT efforts (for technology, talent and tolerance) (Florida, 2002), and the historical relevance of accessibility (now especially at the international scale), cities try hard to be relevant and attractive. As a consequence, international events have been hardly fought as well as other opportunities "to be on the map", while a huge part of the urban budget in a great number of cities goes to efforts in renovation and big company investment, in a sort of second wave beautification process (replicating the city-beautiful North American movement of the late XIXth century and early years of the XXth century) sometimes much more oriented towards the visitors than to the residents.

In relation with the State hollowing or retreat (Brenner, 1999; Rhodes, 1996 and 2007) and the emergence of governance, advocacy and collaborative planning, all sorts of publicprivate combinations are being put in place, with an increased relevance in the future of cities. Portugal and Porto in particular, can be taken as an interesting example here. In fact urbanism - and recent urban regeneration and rehabilitation processes - may be seen as often associated to some kind of "privatization of the city" (Chamusca, 2012; Fernandes, 2006) and to the "triumph of architecture over economic and social geography" (Fernandes, 2011), as private partners interests seem to be much more important than a strategic vision of the city and a long term and sustainable consideration of its inhabitants interests.

As the city agendas seem to be more and more conditioned by the world and regional image of the city and a post-2008 much economically centered idea of development, several authors note the formation and reinforcement of an urban archipelago (an adaptation of the concept of Viard, 1994) and dual city (Sassen, 2006), where a good number of local residents seem to be forgotten and even seen as a problem to the global image of the city instead of being considered a social responsibility of a larger group of spatially organized people (on a national, regional, metropolitan or local administration). Thus, in this private interests friendly policy, "beautification" and "gentrification" actions result as important to reinforce a certain prestige and ambiance, promoting a certain type of touristification that poses new challenges, as the need to produce and regulate a multi-spatial and multitemporal complexity, in between two extremes: a city for all users at all times or a city of pretense paradisiac fragments designed to accommodate an increased number of tourists.

In this respect the growth of public-private partnerships (or PPP's) may be seen as connected to the growth of a certain "laissez faire" neo-liberalism approach - many times 
associated to touristification - as evidence from Oporto and Barcelona show us, and where the relation of space and time is completely forgotten. Recent interventions in Barcelona's Raval (Martinez-Rigol, 2000; Carreras, 2009) and in Porto, in connection with the opportunities as European Capital of Culture in 2001, Football Euro 2004 and the creation of some metro stations are a good examples of private actors power. There, so called urban regeneration - especially real estate rehabilitation - or has the effect in too many cases of getting old houses in renewed areas too expensive and therefore not affordable for common people.

In this process, less evident in Malmo and Toulouse it should be considered the relevance of private actors as times of the economy are reinforced crushing the other temporalities in the city, notably the traditional local times of "normal life" and also and fordist work-free time dualism. That is especially relevant in relation with tourism and in touristifies cities and urban spaces and periods.

\section{Recent urban changes}

\subsection{General dynamics and recent changes in time and space use}

Over the past years societies and territories went through diverse and profound transformations that reinforced the value of multi-temporalities and multi-spatialities, posing new challenges to politics, policies and planning, as the emergence of the concept of chrono-urbanism (Ascher, 1997) signals. The changes are particularly intense on urban areas, with suburbanization, urban explosion, metropolization, urban sprawl, fragmentation and gentrification as some of the processes and dynamics of intense change also associated to a higher concentration of population and economic activity than in any other period in history (Katz et al., 2007), and more intense and variable patterns of mobility and velocity, with a relevant heterogeneity of the everyday citizens' interests and movements.

Politics, policies and planning have also to deal with the fact that cities are no longer limited, and the effect of urban intervention is no longer restricted to its inhabitants. Suburban, dual-urban residents, tourists, students, workers and a wide range of city-users are much more relevant and contribute to a complexity of time-space associations where new and multiple temporalities gain importance in relation to simple movements and time schedules, 
with diverse spaces being used with intensities and type of uses and users along the day, the week and the year.

Across Europe, also in Porto, Barcelona, Malmo and Toulouse, multilevel planning was developed to consider these new dimensions - multi-temporalities, multi-spatialities and diversity of city-users - and was partly focused on improving the conditions of mobility and accessibility within the city-region. Important investments were made on high-speed railway (Barcelona), train travel (Malmö), light rail (Porto) and in intermodality and multimodality plans (Toulouse). However, even if accessibility was strongly reinforced, in some cases especially on the Southwest of Europe - mobility has not increased for much of the cityusers and in fact the combination of suburban car dependence and economic crises has meant less movements for several families, since 2008. Also the retreat of the State in the provision of several services, including cuts on investment for transports networks and social support has meant that mobility is especially good for special groups - as tourists, for example - decreasing for other, as social and spatial injustice increases.

Globally, the Improvement of mobility and accessibility impact diferently in the urban socioeconomic temporalities of different cities. In Porto and Barcelona urban regeneration and gentrification coexist with the maintenance of certain forms of decline in the centre; in Malmoe the centre is intensily appropriated by vistors, while in Toulouse the intercity time has a strong relation with spatial and social disparities in a spread urban area.

\subsection{Light rail and city center renaissance vs. the car dependency of the new poor in Porto}

Recent urban changes in Porto are strongly connected with the metropolization process at the beginning of the $21^{\text {st }}$ century, after intense suburbanization and urban explosion during the last decades of the $20^{\text {th }}$ century. In this context, we've seen the decompression of the central and denser city, and especially its central area, with the emergence of new centers of different type and a relevant role of sophisticated shopping malls. In this context, it is remarkable the Porto city center resilience, with a diversification of the type of inhabitants and new economic dynamics that seem to be very much associated with city-break tourism, university students, low cost air flight (with the airport just $30 \mathrm{~m}$ away from the center) justifying the reference to a "new life of the old center" (Fernandes \& Chamusca, 2013) on a city that was classified as World Heritage by UNESCO in 1996, being elected European Best Destination in 2012 and 2014 by the European Consumers Choice. 
The complex and diversified urban life pattern that emerged from these transformations is characterized by more conflicts and interactions, such as between city-users and cityresidents. These conflicts/interactions are translated in an increased use of the public spaces of the city, within a multi-temporal and multi-spatial pattern that seems to put Oporto more and more as (also) a "city that (almost) never sleeps".

This "new life" of the city center, highlighted by trendy places, different social groups, and alternative movements, with a very relevant role of the "bobo's" (from the French acronym for bourgeois and bohemian) and the reinforcement of a consumption culture, with space, retail and restaurants, atmosphere diversification and a pretense increase of socialization. This intense appropriation of the city center, with more tourists and students but also more suburban residents, led to a new wave of consumption with new shop formats and different forms of privatization of the public space, with bars, cafes and restaurants extending their operation to squares and sidewalks (Fernandes et al, 2013).

In relation to accessibility infrastructure and people mobility, the urban light railway system (going underground in the city center) has been essential to the revival of the city center as its creation and expansion in the 90's and the first years of the 2000 seem to have helped significantly for the revitalization of the areas around the stations, particularly in the central area of the city. The light railway success and the easy connection it establishes with bus, train and air travel have to be considered as very important for the reinforcement of the city center, which was almost only symbolic in the 80's (fig. 1).

\subsection{Less use of transport, less mobility and spatial injustice in Barcelona}

In Barcelona, important recent urban changes are very much related with less use of public transport, less mobility and increased spatial injustice processes. The effects of the economic and social crisis that began in 2008 were intense, with a decline in income and a strong growth of unemployment rates with serious impacts in the reduction of daily mobility, both on public and private transport. In fact, between 2009 and 2012 the road traffic volume and displacements using public transport has decreased in $8-10 \%$, according to Metropolitan Transports of Barcelona and Barcelona City Council.

The economic crisis is also associated with increased social problems, such as housing overcrowding (as younger families can't afford to pay the mortgage or the rent) and the 
need to move to new homes far away from Barcelona city center (Vico, 2006). Although suburban residence seemed to be a good solution, the lack of living conditions (especially for the coldest months) and the inability of family and solidarity networks to provide help so far away from the central city, forced the return of part of these residents to Barcelona and are now living in the streets. In fact, between 2008 and 2013 there has been an increase of 45\% homeless in Barcelona (Sales, 2012).

If the economic crisis affected especially the middle-low classes, it also had important impact on middle-high classes daily-lives, even of the development of high-speed railway connecting new urbanized areas far away from Barcelona (fig. 2), transformed the traditional limits of Barcelona Metropolitan Area (Frago, 2011) and enabled much of those employed in a qualified tertiary sector (businessmen, senior officials, politicians, etc.) to get important gains on their mobility and capacity to work far away from home. Two more issues are essential to understand contemporary Barcelona urban life, especially on its relation with time use and mobility. The first is the growth on the use of bicycle, especially after 2007 (when rental public bike service was implemented), even if the conflicts between pedestrians and cyclists are getting more and more important. The second one, and probably the most important, is the tourism activity. At present, around 7 million tourists coming from abroad visit Barcelona every year - for example, during the Mobile Word Congress's 60,000 tourists visited the city in 4 days - looking for leisure, consumption, business or education, and motivating important changes as the liberalization of shopping hours (opening on Sundays for example), despite opposition from the retail associations.

\subsection{Mobility with growing spatial and temporal injustice in Malmo}

Public transport seems to have increased in all of Sweden's three metropolitan areas during the last decade. In the Malmö region this has especially been the case with an important increase in train travel. The Malmö region has become better connected and the number of labor markets in the province of Scania has subsequently decreased from 16 different labor markets in 1970 to just four in the year 2000, as a concentration process has been complemented with increased mobility. As a consequence the Malmö region is today much more polycentric on a growing urbanized area with an increasingly mobile population (see fig. 3). 
The spatial-temporal landscape has changed dramatically during the last decades with new means of transport, new infrastructure, and densification all playing a relevant role. But the global increase in mobility and increased free time does not seem to be equally spread among the population (Holgersen, 2014), for example, as the mean distance to a grocery store has increase with almost 40\% during the years 1980 and 2004, the gap (in time wealth) between people with and without car has increase has well. It is also possible to notice an increasing polarization between rich and poor (Hedin et al, 2012) with a relevant spatial dimension as certain neighborhoods are less and less favored than others. Nylund has argued that structural inequality and segregation has become downplayed in the comprehensive planning of Malmö, focusing on social cohesion or the design of meeting places and downplaying structural problems (Nylund, 2014). As a consequence what we see is a growing spatial injustice (Soja, 2010), where certain areas are more affected than others, where also occurs a growing temporal injustice (Goodin, 2010), where some can secure more time after the necessary labor is done (including labor that is paid, unpaid or be just part of necessary personal care) than others.

\subsection{Intermodality and multimodality in Toulouse}

Intermodality and multimodality are the keywords of current transportation policies in France. Toulouse is a good example as recent mobility plans were designed to develop methodological tools to shed light on the intermodality and multimodality practices to be adopted, in order to enhance rapid and continuous access to different parts of the city and beyond, and to avoid congestion in certain space-time associations.

Among the major changes currently observed in the French town planning documents better mobility management is a common goal.

First of all, we should note the changes that have a relation to an increased expansion of transport networks, in an effort to try to control urban sprawl, acting on urban, suburban and periurban spaces. Toulouse illustrates this, although still mainly in a prospective dimension. The archipelago system of Toulouse plan shows small suburban cores organized at the level of municipal communities, with better conditions for intermodality on the main intermediate urban center, around a station and a relevant axis of public transport, and all small towns well connected to the nearest large city (fig. 4). 
Secondly, the efforts for building a new governance system are also important. For example, since 2000, the French Organizing Authorities of Transportation in urban agglomerations with more than 100000 inhabitants must establish a mobility council for employers and business managers' activities, which generate large displacements flows. In the Toulouse area, 107 "company travel plans" had been launched before January 2012, representing a potential 172000 employees (approximately 40\% of employees in the Toulouse urban collective transport catchment area), and in all France 9500 "company travel plans" should be set up by 2019 according to ADEME (French Environment Agency and Energy Management.

The third issue has to do with the will of many French cities, including Toulouse, to transform existing centrality poles into relevant multimodal interchange poles. The progressive emergence of interconnection centrality poles in the city illustrates the desire to encourage short trips (in time and distance) by multi-functional concentration and increased conditions of rapid movements especially in travel to work and shopping. At the Greater Toulouse scale, it is possible to say that it is being created, gradually, a multipolar and multifunctional network articulating and segmenting travel according a interrelated public transport service logic and a main and secondary poles distribution system directed to intra and inter-city interaction.

Enhancing the production of housing, services and economic activities on these poles has three major issues: the space and time articulation of travel from one urban pole to another; the fluidity of the poles connection and time conditions regarding speed of access and load limitation; the time intensification and hybridization of functional platforms that combine space and time attendance, appropriation and uses with temporal optimization of multifunctional concentration.

\section{Time policies}

\subsection{How they started, and what they are}

As many authors point out, as Lefevbre (2004) and Ascher (2001), besides social and economic dimensions, recent processes of social and economic transformation with a relevant spatial dimension have also a very important temporal dimension, associated to a 
transition from an industrial standard of synchronized rhythms to a more heterogeneous society in which the everyday experiences are more individualized where a growing number of people have atypical agendas and working hours and supposedly an increasing freedom of space-time choice.

In the context of these transformations, time, and in particular the management and planning of the temporality of spaces, become essential. Planning and policies show greater concern with the multi-temporality of the territories, which is especially evident in the multiplication of actions and mechanisms developed to regulate the various conflicts and ways of space appropriation, for example between those who want to sleep and those who want to have fun, or in the way the urban design conditions the uses (Kärrholm, 2012). A new set of policies has emerged trying to promote a more adequate coordination of problems in time-space associations.

Despite different approaches and concepts of time policies which were developed along the last decades, it is possible to consider three types of time policies: i) urban time policies (Mareggi, 2002) that have a relation to all the public policies that deal with timetables and with the organization of time regulating human relations; ii) time-related policies or conciliation policies (Delfour and Dommergues, 2003) that intend to improve the temporal dysfunctions of cities, namely by regulating the rhythms of the city (supply and demand in terms of time) and the rhythms of people (working and non-working time, for example), and iii) local time policies, concerning all the efforts directed to coordinate working times, timetables of public and private services, and urban schedules with the individual and collective social needs.

As we have said before, Italy played an important role on the development of planning instruments and concepts associated to time planning, especially at local level. From the 1980's several projects and Time Intervention Programs were developed experimentally, but it would be the action of the Italian Minister of Social Affairs - with the approval of the Law 53 in 2000 - that would boost decisively time planning in Italy and all over Europe. The "Turco Law" enforced all cities with more than 30.000 inhabitants to have Territorial Timetable Plans, with proposals for solving all time conflicts identified and timetable maps. A reorganization of the structure of public administration lead to the creation of Time Offices, where accessibility was assumed as the central concept, with Timetable Territorial Plans associated with actions for the improvement of the accessibility to urban spaces and 
public services in non-working times, promoting in particular decentralization and territorial multifunctionality.

Time planning policies were also associated with the so-called "soft politics" including several Time Councils and Mobility Agreements established between local stakeholders and informal bottom-up initiatives, as time banks. So, even if in the majority of countries there's no explicit relation between time policies and planning, chrono-urbanism and the temporal dimension are more and more important. Alongside policies, plans and actions of spatial incidence where time is gaining importance, there are diverse and more informal approaches where the temporal dimension is central in relation to space gaining increasing attention and effects as it is the case of measures that try to manage and coordinate work schedules of public and private services and other needs of each human being, seen as an individual, part of a family or a community element (Mückenberger, 2011).

\subsection{Portugal: between national regulation and neoliberal deregulation}

Contrary to what is happening in other European countries in Portugal there are no explicit time policies, as measures for time management are still very much related with national regulation and modernist-functionalist paradigms. The national directives as DL 48/96 are directed to the regulation of the opening hours of shops, grouping activities into five types and establishing the operating hours for each group, without any consideration for the spatial dimension or specificities of each city. Municipal regulations should respect these guidelines, although small differences can be introduced, with the local decision on this matter considered as final.

There also important informal bottom-up initiatives. Although "slow movements" (as "slow cities" and "slow food") are gaining importance, urban policies don't take into great account time-space issues, as it happens in significant public led urban spaces rehabilitation and regeneration processes (Fernandes \& Chamusca, 2014), where some recognition of the different uses of spaces, along the day and the week, and the numerous time-space conflicts have no consequences in project and action.

Generally, time policies and the concept of chrono-urbanism remain unfamiliar to most planners and politicians in Portugal. As a result, although different cities (and Oporto and Lisbon in special) presents new dynamics, planning ignores the regulation of work schedules, the association of the characteristics of public spaces with their use at different 
times of day and different days of the week, the social rhythms of supply and demand, and the articulation of individual rhythms of work and leisure.

\subsection{Spain and Catalonia: tourism, mobility and innovative plans for social comfort}

Barcelona is a very complex city, with a great number of diversified city-users, where tourists play a very important role (Carreras, 2009). Despite this complexity and fragmentation of uses and interests the city of Barcelona pioneered the implementation of time policies - or at least the consideration of time in planning - in Spain.

Three different measures can be identified. Back in the 1990's, following the Italian example, a set of groups and plans started concentrated their attention on time policies. The first was the Collective of Woman of the Municipal Council of Social Comfort, a group related with the improvement of the role of woman at home and at work. As a result it was demanded an increase of the timetable of nursery and school activities, while there was legislation to allow a greater flexibility in public jobs. The importance of the work/non-work balance and general individual and collective well-being motivated other initiatives, such as the Time and Well-Being Quality Program, designed by the Barcelona municipality at the beginning of 2000 oriented to promote strategic decision-taking in relation to time policies. The second set of actions has to do with the regulation of city uses and timetables. In fact, adapting retail hours to tourism was probably the most significant public action related to time. The Law 3/2014 went even farer, considering certain areas within Barcelona's municipal boundaries as tourist areas, with the right to have specific opening hours for economic activities. After that other plans, in areas as Ciutat Vella or Gràcia neighborhoods have also been implemented to regulate the uses in these districts (as ethnic restaurants) as well as security issues.

The third group of measures was designed to improve intra-metropolitan mobility. Besides the development of the underground network and the mass growth of the bike, special action were implemented to reduce traffic jams: parking was created near railway stations, some parking areas for exclusive use by city residents was implemented and it was approved a set of measures to promote a better use of private transport as legislation that allows public transport or cars only with three or more occupants at some roads. 


\subsection{Sweden: the absence of an explicit time planning, despite of good performance}

Although Sweden often comes out well in comparative analyses of time use and temporal justice, due for example to quite generous possibilities of parental leave and a welldeveloped child care support system (Goodin, 2010), there is no explicit time planning on a regional or municipal level in the country. Planners might address temporality as part of the planning process, but very seldom address the temporal consequences of plans or urban structures, nor do they seem to consider time-space association in any comprehensive way. The existing temporal regulations include, for example, time schedules for public services and public transport. Local temporal regulations may also include permits for selling alcohol (during certain hours of the day or week), for out-door restaurants (during certain weeks of the year) or temporary authorization for mobile vendors. Temporal regulations are, however, often local and not coherently ordered or planned together. The national Swedish rules for shop opening hours were deregulated in 1972, and from the 1990s and onwards, private interests seem to be gaining more influence over temporal planning initiatives. These private initiatives, include, for example, expanded opening hours especially in shopping malls and central retail areas, synchronized retail advertisement campaigns, temporary markets or large scale events and festivals (cf Kärrholm, 2012). Despite temporal change in the Malmö region, with increasing temporal injustice, new means of transport, and a changing temporal structure of everyday life, planning has so far not addressed the question in any explicit way. Instead, and even as temporary complexities of everyday life seem to be increasing, one can see an ongoing territorialisation of large scale areas or city districts for one main function (retail areas, campus areas, residential areas and office areas) continuing the isorhythmic evolution brought by modernist zoning and planning, but this time by means of theming and branding. As these areas keep evolving at an increasingly large scale, both in certain central locations and in the outskirts, the temporal complexity of the urban landscape seems to be diminishing, e.g. leaving large areas empty of life during long hours of the day or the week. Although the basic infrastructure for temporal equality still might seem to be quite good from a European perspective in Malmö and Sweden, recent changes in urban and regional development (for example in Malmö) seems to suggest that temporal inequality is increasing, and thus also points to the need for a more explicit time policy. 


\subsection{France: early time policies, the creation of networks and a fragmented progress}

Following the Italian experiences, several French cities, some of them included on a European program with German, Irish, Italian, and Spanish cities (from 1996 to 2000) have implemented "time policies". The French Delegation for Territorial Planning and Regional Action (DATAR) played a fundamental role in the dissemination of these ideas in the late 1990s - early 2000s. Debates (as "Women times, urban times" in 2000) and reports (as "Time of the city" of MP Edmond Hervé in 2001), were relevant and discussion around the reduction of working time to 35 hours was particularly intense. However, despite the commitment of Lionel Jospin's government to widen the local experiments, the change of government in 2002 put an end to national initiatives in time policies. That is not the case at local scale, as since 2004, twenty territories are grouped within the national network "Territorial Tempo", where there have been discussed and implemented many experiments on synchronization or desynchronization of mobility flows, improving the accessibility in urban areas (especially in the evening), adapting public services schedules, creating "time offices" and even structuring work schedules, schools, services, shopping, and access.

Nowadays, urban policies take greater account of the time-space issues, although in France, unlike Italy, the actions are generally limited to public services. However, progress remain fragile and fragmented, as a result of: i) lack of financial and human resources; ii) insufficient coordination between public and private initiatives; iii) French mayors not having powers as extensive as Italian (Boulin, 2008); iv) time issues appearing in the context of diverse actions without necessary coordination and being at the heart of a urban project (Mallet, 2013); v) time issues often appear too abstract, as they are rarely integrated with reflections, policies or actions of planning agencies or services, and frequently relegate to management services; vi) the promotion of access to services and shops being often reduced to the temporal level, to the expansion of schedules, and at the spatial level, to the road access; and vii) very few activities integrate both time and space.

\section{Looking ahead}

Cities and more expanded and complex urban areas went through important transformations over the past years, with time-space diversification being one of the most remarkable. A mixed use of space along the 24 hours of the day territorializes the idea of a 
city that never sleeps but within a multi-spatial and multi-temporal complexity, some people become more and more hypermobile, as they are able to be always anywhere doing anything and have much free time, in sharp contrast to the typical "nailed to the ground" industrial time workers/unemployed/sub-employed and all kinds of in-between situations.

However, despite all changes, planning and time policies, as well as the management of time-space diversity and the regulation of conflicts in the 24 hours city looks to be very much lagging behind, showing evident difficulties to answer increased time-space relevance and complexity. Articulation between free time and work time, in order to provide an answer to the individualized rhythms and the relations between spaces, concerning accessibility, and having social and spatial justice in mind is especially in need, among several challenges. Also, the articulation between spatial and temporal dimensions (considering both longer and shorter time periods) call for the operationalization of chronourbanism and an explicit introduction of time in the planning mechanisms and instruments.

In this direction there are different aspects to consider. First of all a new governance approach is needed, capable to promote a better articulation between the public and private sectors and civil society as a whole, in order to regulate interests and conflicts, assuming that common good should prevail and the most fragile (people or space) must be especially considered. Speaking of governance in the context of a neoliberal deregulation process meaning a reinforced importance of urban planners and managers role in considering bottom-up actions and informal movements related with time policies and all type of spatial and temporal relations. In fact, in a more informal approach, time policies are promoted locally by diverse civic movements such as time banks (Santos, 2012), and initiatives related to slow cities, slow food, slow ageing and time oriented and space-based cooperation for development are gaining recognition as soft politics.

If collective action is key in urban and time policies for the following years, competitiveness, cohesion and sustainability are the main principles that seem to structure urban planning and intervention. Competitiveness is understood as a priority especially in a period of economic stagnation and not only marketing initiatives but also other more local grounded projects and some "shrinking" urban policies have gained relevance, translating into the promotion of the diversity (social, economic, morphological, as well as spatial and temporal) and the vitality of the economy. But social and territorial cohesion and its relation with the increasing diversity and individualization of time periods, cultures, people and daily life patterns, seem destined to be central in planning having in mind a sustainable territorial 
strategy that is effectively capable to promote the mixture of uses and users at different times, combating exclusion, asymmetries and specially intense temporal, spatial and social conflicts in increasing multi-cultural and dual cities.

In Porto the debate seems to be centered on multimodality and in the need to offer transport where people live. If mobility and accessibility are central issues, multimodality and transport network look essential to answer space and time individual diversified needs for all. Much harder is to say what solutions may be adopted for this city and the urban polycentric region it commands, when everyone seems to have special time-space needs and several are excluded by restrained mobility to the right to the city.

In Barcelona, the governance of accessibility in sprawl is a main concern. Urban planners and managers look hard for policies able to improve public transport and provide better access to the central areas of the city, although the growth of low-density urban areas is easily associated to the reinforcement of the private car. Besides mobility issues, the regulations of retail timetables - in order to adapt them to all kind of city-user, cityinhabitants and interests - is also a complex challenge that is very much on the table, as it is seen as a key element for the preservation of urban dynamics in the city center.

In Malmö, we have seen increased possibilities of mobility in a growing and more well connected urban landscape. However, this does not in itself secure a spatial-temporal justice among citizens - on the contrary, differences associated with the time and space use of the citizens, as well as of different urban areas, seems to be increasing. The solution to these changes are not easy to address, but at least it seems clear that the question of space and time wealth needs to handled at the level of urban and regional planning in a more systematic way than hitherto.

In Toulouse, the expansion of the transport system is much needed and it is expected to answer on a more coherent and cooperative way to the mobility expectations of users that have a more time variable use of time, to provide answer to serious transportation policy limitations, independent of each administrative unit. Some of the challenges to be faced in next times are the organization of the transport system, with increased accessibility in the suburban and peri-urban area, and the need to answer excessive policy segmentation and a lack of transport coordination. If it goes as we would like to see, time policies are expected to evolve to a second stage and start considering temporary and flexible time transport modes, in order to improve work, shopping and leisure access and to answer the complex organization of much more diversified daily-lives. 


\section{Conclusions}

Time-space diversification is characteristic of contemporary cities, where everyday lives and city-users interests are greatly heterogeneous. However, despite important transformations in urban live, analysis in four different European countries, and taking Porto, Barcelona, Malmo and Toulouse as case study, points out that there is not an holist perspective to time management and to temporal integration in planning, at least not something similar to the Italian time-plan experience or other important initiatives developed across Europe since the 1990's. Even if accessibility and mobility are well cared for in planning (sometimes especially in debate and not so much in action) and rehabilitation/regeneration are important (although often mistaken with beautification, touristification and gentrification), it is possible to note a practical absence of time management and planning on much of the projects or much of other explicit time policies.

Evidence is somehow confusing and contradictory, considering the recent dynamics of timespace diversification and hypermobility of cities with a tendency for $24 \mathrm{~h}$ opened 365 days a year, as well as the growing pressure for new mobility and conflict management. If some difficulties and especially the recent crisis explain part of the absence of chrono-urbanism related considerations, the fact is that some planning exercises look outdated, too focused on close proximity and on linear time, where exceptions have local dimension and a close relation with public/private cooperation.

Anyway, even if there are no explicit time policies, and neoliberalism is not the best of the context for planning, it is possible to say that public authorities are encouraging time use diversity, as they seem favorable - at least tolerant - to the enlargement of opening hours of shops and bars, and somehow promote an increased deregulation of economic activity. That is specially noted in the most "touristified" spaces, where economic interests seem to dominate politics. Therefore, policies tend to see (practically) all that sells as favorable for local and regional development and as factors of increased attractiveness for private investment and visitors increased expenditure, which comes along different forms of privatization of public space and increased mix use of spaces along a longer time of the day.

Two questions arise, on the line of Habermas' (1989) exhaustion of the utopian energies: is there still space and time for hope, and does planning make sense on a neoliberal context? 
Theoretical and empirical evidence collected from Portugal, Spain, Sweden and France, and discussions that occurred in the context of the Chronotope project lead us to believe that cities and societies need integrated and effective planning to find prosperity, and new convictions that consider the relational complexities (Healey, 2006) and time-space iterations are very much-needed.

Against the triumph of the stronger, centralism and increased social and spatial inequality we believe that a new set of instruments of planning is needed for new time-space geography. Within an integrated time-space planning four principles look central, related with the production of wealth, the promotion of well-being, the reinforcement of spatial and social justice and cohesion and the continuous preoccupation with citizenship and the existence of conditions capable to guarantee the universal right to the city.

In this direction, the development of collaborative and strategic initiatives, the consideration of multiple times, spaces, uses, rhythms and interests, as well as the establishment of urban governance schemes look key factors, and are in the base of some preliminary suggestions/conclusions for a reinforced time policy in our cities:

- "Virtual" mobility could profit from developments on information and communication technologies (ICTs). This way it may be possible to limit the number of journeys (by means of video conferencing, co-working spaces...), even if at the same time certain journeys could be saved, other are bound to be induced;

- Multipolar urban spaces with concentration of retail and services at nodes situated on residence and job high-density areas, should promote shorter distances for frequent necessities;

- The articulation between urban planning and transportation networks (more than between planning and mobility), that considers the temporal dimension of accessibility and the global coherence of polycentric regions may severely increase the access to the city by an enlarged group of residents and all type of city users;

- A new balance in transport system organization, with increased adaptive (and proactive) efforts to answer heterogeneous society needs and aspirations, contrary to a synchronic vision of urban development, would be a relevant step in the direction of a society with diverse users times and mobility rhythms; 
- Permanent conciliation of public and private services timetables, considering municipalities, associations and civil society, looks inevitable to promote a better response to relevant individual needs and interests that are less and less standardized;

- More accessibility and security at different days and hours, has to consider that lifestyles are more and more individualized, that the majority of city-users don't have a traditional schedule as the separation between "rush hours" and "dead hours" is no longer so evident;

- The option for urban spaces of multiple uses on the choice of design or rehabilitation of public spaces, in respect for local culture and history, may respond more efficiently to different uses and needs, in distinct periods of the day, week and year;

- Reinforcing the balance between the times devoted to work or leisure, promoting initiatives of "temporal saving", such as time banks or shared travelling have to be seen as important initiatives in the context of a new set of time oriented policies and measures;

- The promotion of social mixture and meeting places and times is very important in a central political need of cities, that of promoting citizenship in the context of multilevel strategic-collaborative planning when governance within city regions is essential in the construction of a better (and people and space based) future.

\section{References}

ASCHER F., (1997) «Du vivre en juste à temps au chrono-urbanisme», Les Annales de la Recherche Urbaine, $\mathrm{n}^{\circ}$ 77 , p. 113-121.

ASCHER, F. (2001). Les nouveaux principes de l'urbanisme. Paris, L'aube.

ASCHER, F. (2002). L'émergence de la societé hipertexte. Futuribles: 8.

BOULIN J.-Y., (2008) Villes et politiques temporelles, Paris, La Documentation française, 244 p.

BOULIN J.-Y. \& MÜCKENBERGER U., (2002) La ville à mille temps. Les politiques des temps de la ville en France et en Europe, La Tour d'Aigues, Éd. de l'Aube-DATAR, 222 p.

BRENNER, N. (1999). "Globalisation as reterritorialisation: The re-scaling of urban governance in the European union." Urban Studies 36(3): 431-451.

CARRERAS I VERDAGUER, C. (1993) Geografia urbana de Barcelona:espai mediterrani, temps europeu, OikosTau, Vilassar de Mar.

CARRERAS I VERDAGUER, C. (2009) "La centrificación, una propuesta de clarificación conceptual" a La cuestión del centro, el centro en cuestión, Martínez i Rigol, S. ed, Milenio, Lleida, pp. 37-42.

CHAMUSCA, P. (2012) Governança e regeneração urbana: entre a teoria e as práticas. FLUP, Tese de Doutoramento. 400 p. 
DELFOUR, C.. \& DOMMERGUES, P.. (2003) Time-related policies in France. In Dommergues, P. \& Delfour, C. (ed.) (2003) Conciliation policies in France. Bulletin de la coordination nationale et transnationale, $\mathrm{n}$. 0 7-8. Afet Editions, Paris.

DESSE R-P., GASNIER A., GUILLEMOT L., PUJOL Ch., SOUMAGNE J. (dir.) (2014), La ville au rythme du commerce, synthèse de recherche sur l'urbanisme spatio-temporel menée dans le cadre du contrat européen Chronotope (2011-2014), in Le quatre pages du PUCA, n¹5, avril 2014.

DIELEMAN, F.\& FALUDI, A. (eds.) (1998) “Polynucleated Metropolitan Regions in Northwest Europe," European Planning Studies, Special Issue .

FERNANDES, J.A.R. (2006). "O planeamento urbano e a coesão social: a perspectiva europeia e o caso de Portugal." Cidades 3(5): 11-36.

FERNANDES, J.R. (2011). "Area based initiatives and urban dynamics: the case of Porto city centre." Urban Research \& Pratice 4(3): 285-307.

FERNANDES, J.R. \& CHAMUSCA, P. (2013). "Dinâmicas recentes e urbanismo na área central do Porto. Morte, resistência, resiliência e elitização no centro histórico e na Baixa", in FERNANDES, José Rio \& SPOSITO, Maria Encarnação (org.) "A nova vida do velho centro nas cidades portuguesas e brasileiras". FLUP/CEGOT, pp. 83-96

FERNANDES, J.R.; CHAMUSCA, P. \& FERNANDES, I. (2013). Aliados Avenue and Centre of Porto: Uses and Movements. Porto Vivo, SRU. ISBN: 978-989-98335-6-2

FERNANDES, J.R., \& CHAMUSCA P. (2014), Urban policies, planning and retail resilience. Cities (36), 2014, pp. 170-177 http://dx.doi.org/10.1016/j.cities.2012.11.006 (ISI, IF - 1,545)

FLORIDA, R. (2002) The rise of the creative class: and how it's transforming work, leisure, community and everyday life, Basic Books.

FRAGO, LL. (2011). La metamorfosi del centre a les capitals comarcals: entre tradició i post-modernitat. University of Barcelona, Human Geography Department, Doctoral Dissertation.

GASNIER A., GRELLIER A. (2014), Commerce et renouvellement urbain : une interaction palliative des maux de la ville française ? In Le commerce dans tous ses états, espaces marchands et enjeux de société, Arnaud Gasnier et Nathalie Lemarchand (Dir.), Collection Espace et territoires, Presses Universitaires de Rennes, p. 71-80, $359 \mathrm{p}$.

GASNIER A., LESTRADE S. (2014), Commerce et étalement urbain : en France, le modèle " centre/périphérie " fonctionne-t-il toujours ? In Le commerce dans tous ses états, espaces marchands et enjeux de société, Arnaud Gasnier et Nathalie Lemarchand (Dir.), Collection Espace et territoires, Presses Universitaires de Rennes, p. 71$80,359 \mathrm{p}$.

GOODIN, R. E. (2010). Temporal justice. Journal of Social Policy, 39(01), 1-16.

HABERMAS, J. (1989) 'The New Obscurity: The Crisis of the Welfare State and the Exhaustion of Utopian Energies', The New Conservatism: Cultural Criticism and the Historian's Debate, pp. 48-70, p. 5. Cambridge, MA: MIT Press.

HALL. P \& PAIN, K. (eds.) (2006) Polycentric Metropolis: Learning from Mega-city Regions in Europe. London, Sterling, VA: Earthscan.

HALL, P. (2014) Creating transport corridors: refreshing the places other transport hasn't reached. Regions and Cities. Where Policies and People Meet, OECD, pp 211-219.

HALL, T. The entrepreneurial city: new urban politics, new urban geographies, Progress in Human Geography, June 199620: 153-174

HARVEY, D. (1990) The condition of Postmodernity: an enquiry into the origins of cultural change. Oxford, Blackwell $378 \mathrm{p}$.

HEALEY. P. (2006) Relational complexity and the imaginative power of strategic spatial planning, European Planning Studies, 14:4, 525-546, DOI: 10.1080/09654310500421196 
HEDIN, K., CLARK, E., LUNDHOLM, E., \& MALMBERG, G. (2012). Neoliberalization of housing in Sweden: Gentrification, filtering, and social polarization. Annals of the Association of American Geographers, 102(2), 443-463.

HERVE, E., (2001) Temps des villes, rapport parlementaire à la demande de Claude Bartolone, Ministre délégué à la Ville, et de Nicole Perry, Secrétaire d'État aux Droits des femmes et à la formation professionnelle, 73 p.

HOLGERSEN, S. (2014). The Rise (and Fall?) of Post-Industrial Malmö. Investigations of city-crisis dialectics. Lund University.

KÄRRHOLM, M. (2012) Retailising Space; Architecture, Retail and the territorialisation of Public Space. Ashgate. Farnham.

KATZ, B., A. ALTMAN, et al. (2007). An agenda for the urban age. The Endless City. R. Burdett and D. Sudjic, Phaidon Press Inc.

LEFEVBRE, H. (2004), Rhythmanalysis: Space, Time and Everyday Life, Continuum.

MALLET S. (2013) "Aménager les rythmes: politiques temporelles et urbanisme», EspacesTemps.net, 15.04.2013 [en ligne], http://www.espacestemps.net/articles/amenager-les-rythmes-politiques-temporelleset-urbanisme/

MAREGGI, M. (2002) 'Innovation in Urban Policy: The Experience of Italian Urban Time Policies', Planning Theory \& Practice, 3: 2, 173-194.

MARTINEZ RIGOL, S. (2000) El Retorn al centre de la ciutat, University of Barcelona, Human geography Department, Doctoral Dissertation.

MAULAT J. (2012) Développement du transport ferroviaire périurbain et mutation des référentiels de l'action publique : vers une cohérence renouvelée entre réseau ferré et territoire?, Revue Géographique de l'Est_[En ligne], vol. 52 / 1-2.

MÜCKENBERGER, U. (2011). Local Time Policies in Europe. Time and Society 20(2) SAGE, 2011, pp. 241-273.

NEUMAN, M.L \& HULL, A. (2011) (eds.) The Futures of the City Region. Routledge.

NYLUND, K. (2014). Conceptions of justice in the planning of the new urban landscape-Recent changes in the comprehensive planning discourse in Malmö, Sweden. Planning Theory \& Practice, 15(1), 41-61.

RHODES, R. A. W. (1996). "The new governance: Governing without government." Political Studies 44(4): 652667.

RHODES, R. A. W. (2007). "Understanding governance: Ten years on." Organization Studies 28(8): 1243-1264.

SALES, A. (2012) La situació de les persones sense llar a Barcelona el 8 de noviembre de 2011 i l'evolució dels serveis residencials, Xarxa d'Atenció a persones Sense Llar de Barcelona, Barcelona.

SANTOS, M. (2012): "Começos e Sentidos do Banco de Tempo em Portugal», in Encontro Internacional Comemorativo dos 10 Anos do Banco de Tempo em Portugal, Lisboa, 22 de Junho de 2012.

SASSEN, S. (2006). Cities in a World Economy. London, Sage Publications.

SERRA, J., CARRERAS, C. I Martínez-Rigol S. (2011), Atles de Barcelona. Ajuntament de Barcelona, Barcelona.

SOJA, E. W. (2010). Seeking spatial justice. U of Minnesota Press, Minneapolis.

SOUMAGNEJ. (Dir.), Desse R-P.,Gasnier A., Grellier A., Guillemot L.(2014), Aménagement et résilience du commerce urbain en France, L'Harmattan, coll. Itinéraires géographiques, 269 pages.

VIARD, J. (1994) O arquipélago da sociedade , Éditions de l'Aube.

VICO, C. (2006) "Las urbanizaciones: los nuevos barrios periféricos de la región metropolitana de Barcelona" a Barcelona y Sao Paulo cara a cara: procesos metropolitanos a la hora de la globalización, eds. C. Carreras i Verdaguer i A.F. Carlos, Davinci, Barcelona, pp. 211-219. 


\section{Annex}

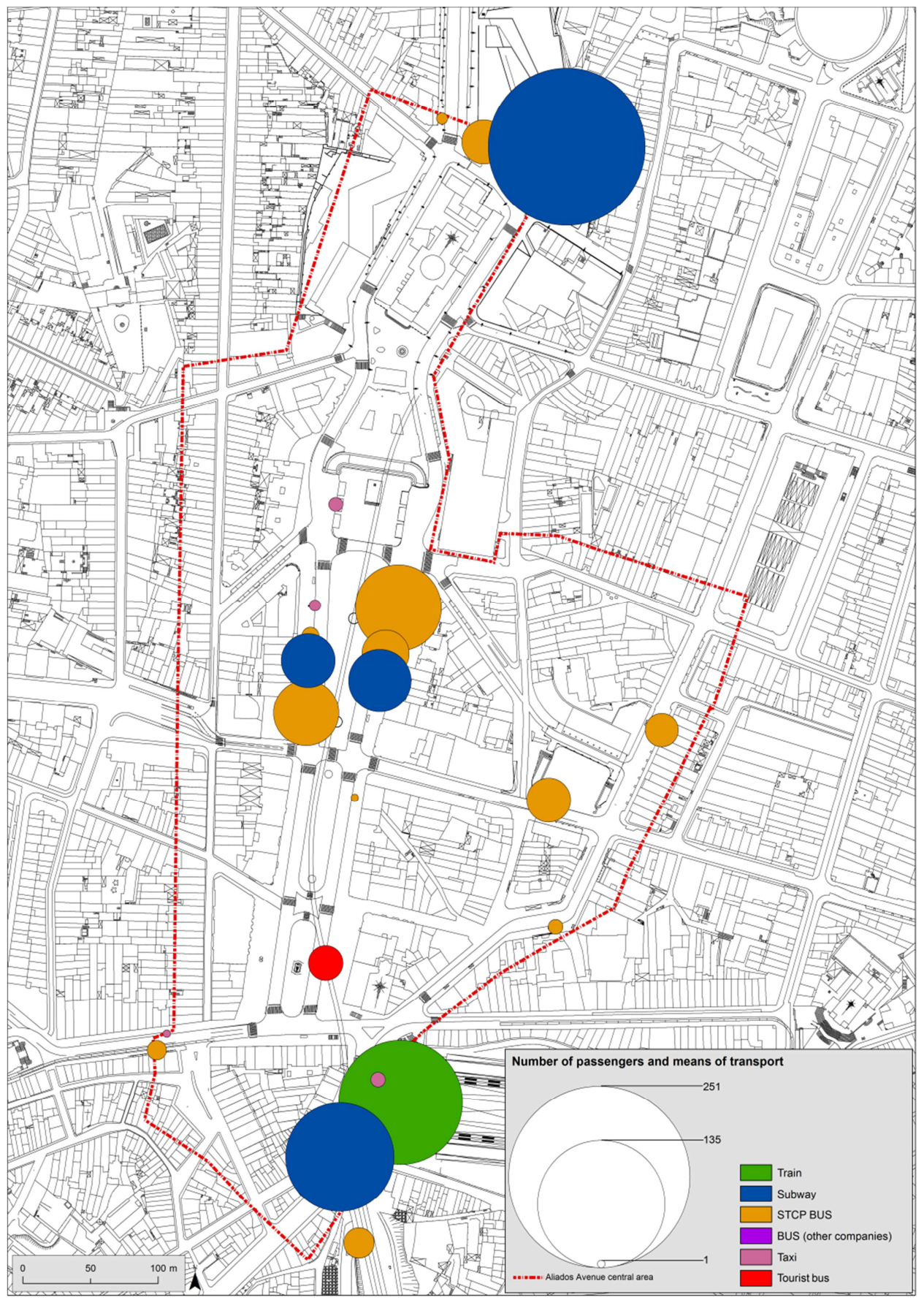

Figure 1 - Arrival of passenger at Aliados Avenue central area, in August 2013 between 7:55 and 8:05 am 


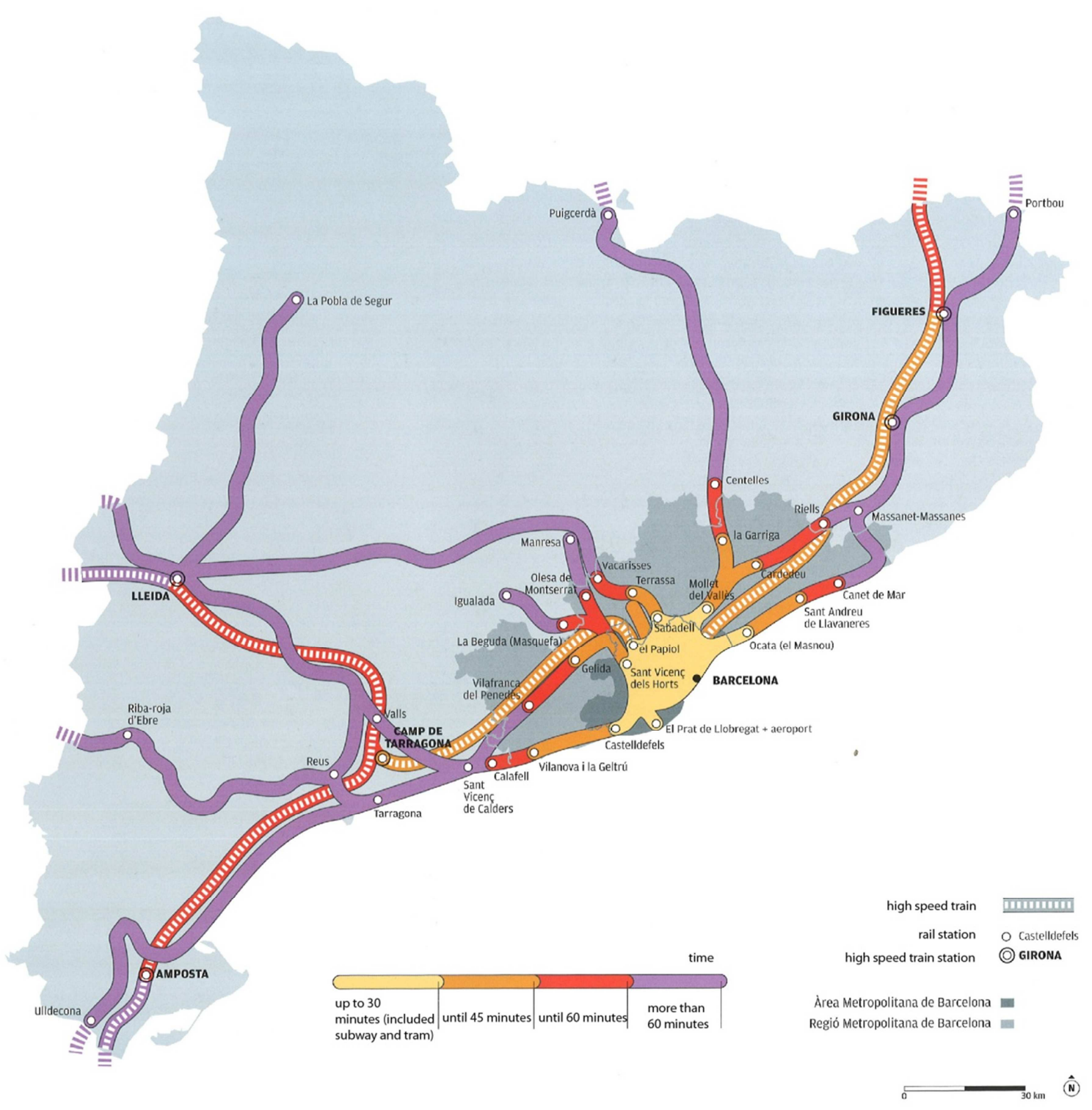

Figure 2. Time access to Barcelona by train. Source: Serra, J., Carreras, C. \& Martínez-Rigol, S., 2011. 


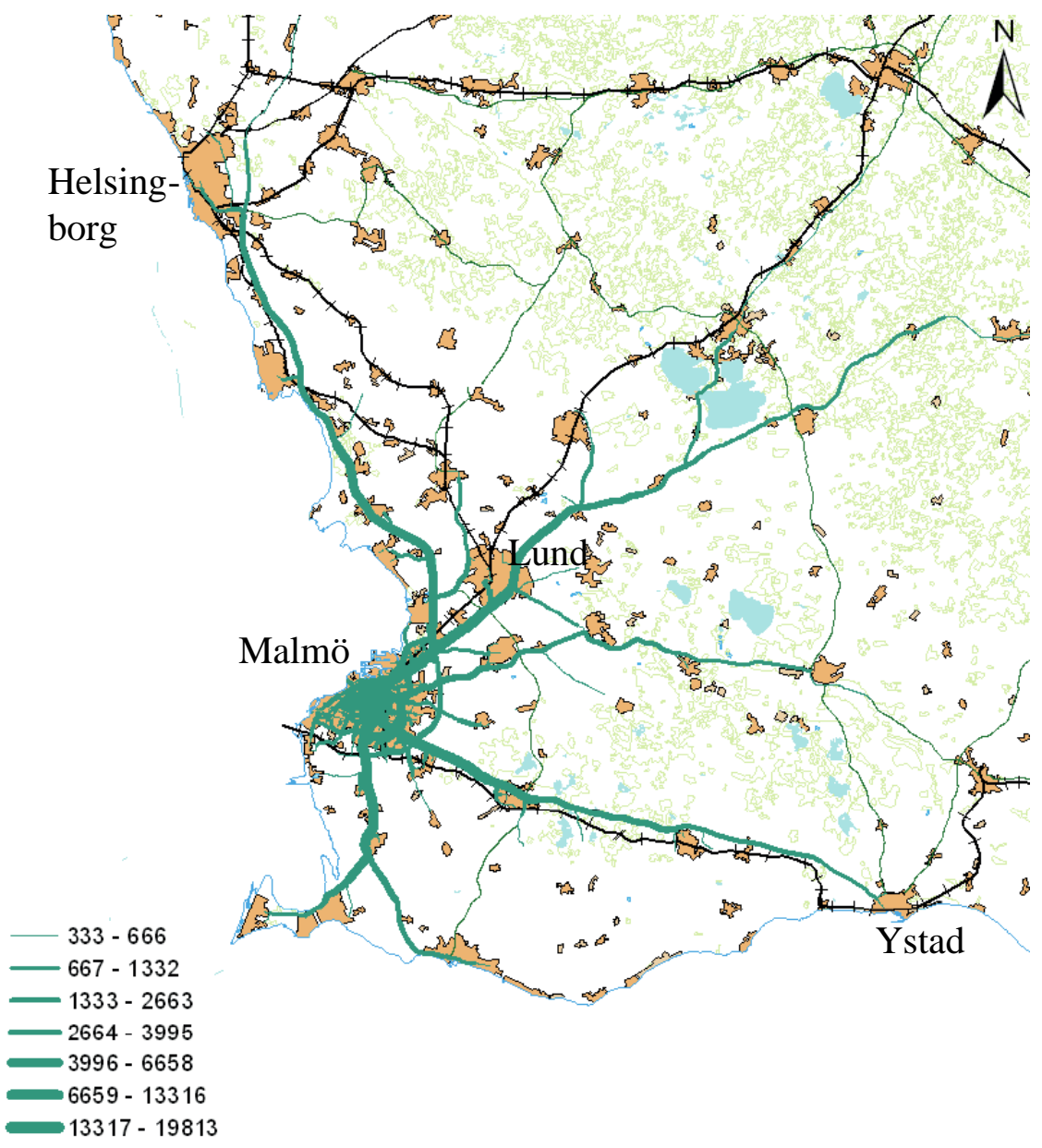

Figure 3. Commuter travelling into Malmö everyday (Source: Arbetspendlingens struktur i Skåne, Region Skåne, Malmö, 2008). 


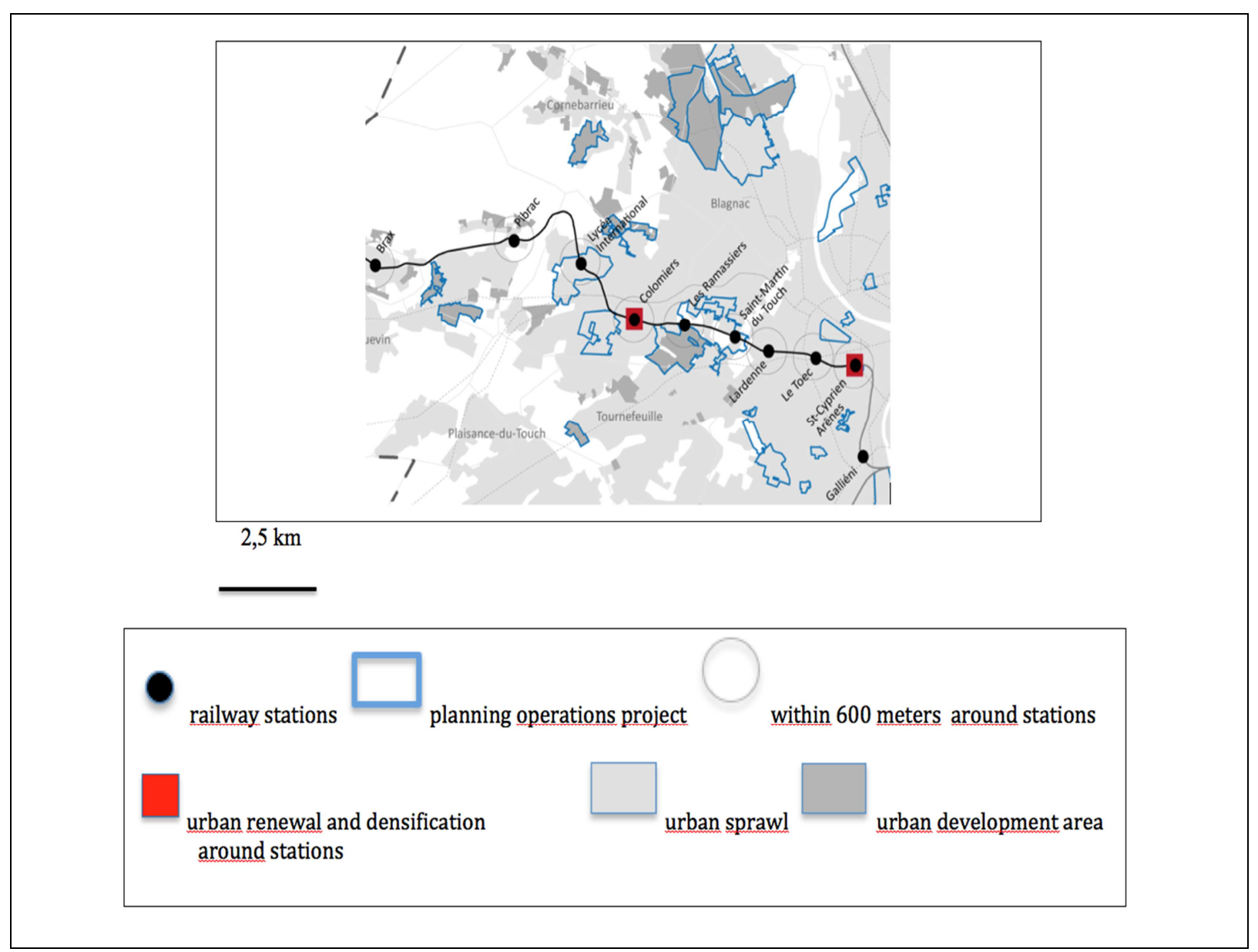

Figure 4. Western railway densification axis of Toulouse suburban area (source J. Maulat, 2012) 